\title{
PROBING IN VITRO TRANSLATION PRODUCTS WITH MONOCLONAL ANTIBODIES TO A 15.2 kD POLYPEPTIDE SUBUNIT OF PHOTOSYSTEM I
}

\author{
by \\ GUNILLA HØYER-HANSEN, LISBETH SKOU HØNBERG \\ and
}

PETER BORDIER HØJ'

\begin{abstract}
Department of Physiology, Carlsberg Laboratory, Gamle Carlsberg Vej 10, DK-2500 Copenhagen Valby.

"Present address: Department of Plant Physiology, The Royal Agricultural University, Thorvaldsensvej 40, DK-1871 Copenhagen V.
\end{abstract}

Keywords: Barley, immune-blot assay, immunoprecipitation, mRNA, viridis- $z b^{63}$

Three monoclonal antibodies to the $15.2 \mathrm{kD}$ polypeptide subunit of a barley photosystem 1 (PSI) particle have been characterized. Immune-blot assays showed that there are at least two different antigenic sites on the polypeptide. The antibodies were employed for immunological identification of polypeptides translated in vitro in an mRNA-dependent cell-free rabbit reticulocyte lysate. The IgG's, CMp15.2:1 and CMp15.2:2, precipitated a polypeptide of molecular weight $23 \mathrm{kD}$ from in vitro translates primed with poly $\mathrm{A}^{+} \mathrm{RNA}$ but not when chloroplast RNA from greening barley was used. No $23 \mathrm{kD}$ precipitation band was found, if these antibodies were mixed with a PSI particle preparation before they were added to the translate. We conclude that the putative iron-sulphur centre binding $15.2 \mathrm{kD}$ PSI subunit is synthesized on cytoplasmic ribosomes as a $23 \mathrm{kD}$ precursor, and is coded by nuclear DNA. Transcripts for the $15.2 \mathrm{kD}$ polypeptide were also found among the poly A'RNA of the PSI mutant viridis- $z b^{63}$.

\section{INTRODUCTION}

The polypeptides involved in photosystem I activity have been tentatively identified by comparing electrophoretograms of wild-type thylakoids with those of mutants deficient in PSI (6, $11,12,14,30,31)$. In addition, photosynthetically active PSI particles have been iso- lated with polypeptide patterns partially complementary to those missing in the PSI mutants $(4,5,24,27,31,42)$. These PSI particles contain from 3 (31) to 7 or $16(27,29)$ Coomassie staining polypeptides depending on the method and species used. All particles contain the chlorophyll $a$-protein 1 , the reaction centre protein

\footnotetext{
Abbreviations: $\mathrm{Chl}_{\alpha}-\mathrm{Pl}=\mathrm{P}-700$ chlorophyll $a$-protein $1 ; \mathrm{CM}=$ Carlsberg Monoclonal; $\mathrm{DNA}=$ deoxyribonucleic acid; DTT = dithiothreitol; EDTA = ethylenediamine tetraacetate; EGTA $=$ ethyleneglycol-bis- $(\beta$-amino-ethyl ether) $\mathrm{N}, \mathrm{N}$-tetraacetic acid; HAc $=$ acetic acid; $\mathrm{Ig}=$ immunoglobulin; $\mathrm{kD}=$ kilodalton; $\mathrm{p}=$ protein; $\mathrm{PAGE}=$ polyacrylamide gel electrophoresis; poly $\mathrm{A}=$ polyadenylated; $\mathrm{PSI}=$ photosystem I; $\mathrm{pt}=$ plastid; RNA = ribonucleic acid; SDS = sodium dodecyl sulphate; WT = wild-type.
} 
of PSI. One preparation also contains the polypeptides involved in light-harvesting for PSI (27, 28, 29). The PSI light-harvesting chlorophyllproteins, LHCI-730 and LHCI-680, have recently been isolated from maize and characterized (3). The holoprotein of LHCI-730 has an apparent molecular weight of $40 \mathrm{kD}$ and is resolved by urea-SDS-PAGE into three polypeptides of molecular weights $21,22.5$ and $24 \mathrm{kD}$, whereas LHCI-680 with an apparent molecular weight of $25 \mathrm{kD}$ consists of a 20 and a $25 \mathrm{kD}$ polypeptide. The function of the other polypeptides in the different PSI particles has not yet been determined. However, there is circumstantial evidence that one or both of the 18.3 and $15.2 \mathrm{kD}$ barley polypeptides represents the iron-sulphur centre proteins that serve as electron acceptors from photosystem $I(31,32,39)$.

The sites of synthesis of the PSI polypeptide subunits have been studied in pea by in vivo labelling of polypeptides in the presence of inhibitors of protein synthesis (29). MULLET, Grossman and CHUA (29) isolated a PSI particle containing 16 polypeptide subunits using the method described in (27). They found that chlorophyll $a$-protein 1 and subunit 16 are synthesized on chloroplast ribosomes, whereas subunits $3-7,12,13$ and 15 are products of cytoplasmic protein synthesis. The site of synthesis of the other six subunits could not be established with this method. Using a simpler Spirodela PSI particle containing seven subunits Nechushtai, Nelson, Mattoo and EdelMAN (33) found that subunit I (chlorophyll $a$-protein 1), V and VIb are synthesized inside the chloroplast, whereas the mRNA for subunit II is translated in the cytoplasm. With translation assays in a cell-free rabbit reticulocyte lysate, transcripts for chlorophyll $a$-protein 1 were found among spinach plastid RNA, whereas those for subunit 2 were in the cytosolic RNA (42). The immunological identification of the translated products was carried out with rabbit antibodies (42).

The antibody specificity is critical in determining the site of synthesis of a given polypeptide. Monoclonal antibodies directed against a single antigenic determinant (23) would therefore be an ideal choice for immunoprecipitation experiments. We have prepared monoclonal antibodies to the Coomassie stainable polypeptide subunits of the barley PSI particle $(15,18$, 21). Using three different monoclonal antibodies to a $15.2 \mathrm{kD}$ PSI polypeptide subunit we have optimized immunoprecipitation with these monoclonal antibodies and determined the intracellular location of transcripts for this protein.

\section{MATERIALS AND METHODS}

\subsection{Plant material}

Seeds of wild-type barley (Hordeum vulgare L., cv. Svalof's Bonus) and the recessive nuclear gene mutant viridis- $z b^{6.3}(43)$ were germinated in tap water moistened vermiculite. When used for thylakoid or PSI particle isolation the seedlings were grown in continuous light (1700 lux) at $23^{\circ} \mathrm{C}$ and harvested seven days after sowing. For RNA isolation the wild-type seedlings were grown for 5 or 6 days in the dark at $23^{\circ} \mathrm{C}$ followed by 6 hours of illumination (1700 lux) prior to harvesting. The mutant was grown for 5 days in continuous light followed by 24 hours in the dark and 2 hours in the light before harvest. This procedure was necessary to distinguish the mutant seedlings from the wild-type phenotype by their paler green colour.

\subsection{Isolation of PSI particles and purified thyla- koids}

Photosystem I particles were isolated using the zwitterionic detergent Empigen BB (31). Thylakoids were purified by flotation in a discontinuous sucrose gradient (19). The membranes were stored in $0.1 \mathrm{M}-\mathrm{Na}_{2} \mathrm{CO}_{3}-0.1 \mathrm{M}-\mathrm{DTT}$ at $-20^{\circ} \mathrm{C}$. Chlorophyll was determined according to ARNON (2) and protein according to LOWRY (26) with bovine serum albumin as a standard.

\subsection{Isolation of mRNA}

RNA was prepared using a slight modification of published procedures $(9,34,36)$. Seedlings ( $100 \mathrm{~g}$ ) were homogenized in a modified Braun mixer (22) using $300 \mathrm{ml}$ of $5 \mathrm{M}$-guanidine- $\mathrm{HCl}$, 10 mM-Tris- $\mathrm{HCl}$ pH 8.5, 5 mM-EGTA, 20 mM-DTT, $0.1 \%$ lauryl sarcosine and $0.01 \%$ 
octanol. The homogenate was filtered through 2 layers of $31 \mu \mathrm{m}$ nylon mesh and centrifuged 20 minutes at $2600 \times \mathrm{g}$. The supernatant was decanted and $1 \mathrm{M}$-HAc was added to adjust the $\mathrm{pH}$ to 5.5 , prior to addition of $225 \mathrm{ml}$ cold $96 \%$ ethanol. Nucleic acids were precipitated overnight at $-20^{\circ} \mathrm{C}$ and collected by a 20 minutes centrifugation at $2600 \times \mathrm{g}$. The pellets were then washed twice with $70 \%$ cold ethanol and once with $96 \%$ ethanol. The crude RNA was dissolved in $40 \mathrm{ml}$ sterile $5 \mathrm{M}$-guanidine- $\mathrm{HCl}, 25 \mathrm{mM}-\mathrm{Na}$ citrate pH 7.0, 5 mM-DTT and 10 mM-EDTA, and phenolized thrice. The RNA was recovered from the final waterphase by ethanol precipitation overnight at $-20^{\circ} \mathrm{C}$ followed by centrifugation and two times washing with $70 \%$ ethanol as above.

The chromatography and isolation of poly $\mathrm{A}^{+}$ RNA on poly U-Sepharose 4B (Pharmacia Fine Chemicals) was conducted as described in (7). Two fractions were collected. Poly ARNA is the RNA eluted with the first column volume after application of total RNA. Poly $A^{+}$RNA is the RNA eluted with $90 \%$ formamide. Chloroplast RNA was isolated from intact chloroplasts according to POULSEN (35).

\subsection{In vitro translation}

The isolated RNA was used to prime in vitro translation using rabbit reticulocyte lysate (Amersham N.90), and ${ }^{35} \mathrm{~S}$-methionine (New England Nuclear $887 \mu \mathrm{Ci} / \mathrm{mmol})$. The optimal amount of RNA in each assay was determined by titration. The translations were performed according to the procedure supplied by the manufacturer.

\subsection{SDS-PAGE and immune-blot assay}

Electrophoresis in SDS was performed as described by CHUA and BENNOUN (10). Immediately after completion of the electrophoretic run the polypeptides were transferred from the SDS-gel to nitrocellulose filters $(18,21,40)$. These were used for immune-blot assays, exactly as described previously (21). Bands were visualized using peroxidase coupled rabbit antimouse immunoglobulins (DAKO Immunoglobulins A/S P 161).

\subsection{Monoclonal antibodies and Ig class deter- mination}

Three different monoclonal antibodies to the 15.2 kD PSI protein, CMp15.2:1, CMp15.2:2 and CMp15.2:3 were obtained from the same fusion (21), using PSI particles as the antigen. The amount of monoclonal antibody used was estimated by multiplying the hybridoma cell concentration by $0.05 \mathrm{ng}$, which is the amount of antibody that one hybridoma cell secretes during 48 hours (38).

The class of secreted antibodies was determined by an immunodiffusion test (16).

\subsection{Immunoprecipitation}

The method used is a modification of published procedures $(1,41)$. SDS $(20 \%)$ was added to the translate to give a final concentration of $2 \%$. After boiling for 3 minutes the translate was diluted 10 times with $300 \mathrm{mM}-\mathrm{NaCl}, 1 \%$ Triton $\mathrm{X}-100,50 \mathrm{~mm}$-Tris-HCl pH 8.0. Each precipitation started with at least $1.2 \times 10^{6}$ acid precipitable cpm.

The diluted translate was first incubated for one hour at room temperature with $50-100 \mu \mathrm{l}$ of a 1:1 slurry of protein A-Sepharose (Pharmacia Fine Chemicals) in the above buffer. The protein A-Sepharose was pelleted by centrifugation. The translate was transferred to another tube to which $25 \mu$ l of hybridoma supernatant $(\sim 0.63 \mu \mathrm{g}$ of antibody) was added. After overnight incubation at $4{ }^{\circ} \mathrm{C} 50-100 \mu \mathrm{l}$ of a $1: 1$ slurry of protein A-Sepharose was added and allowed to react for at least one hour at room temperature. When the antibody was an IgM, $25 \mu$ l of rabbit immunoglobulins to mouse immunoglobulins(DAKOZ 109) was added 2 hours prior to addition of protein A-Sepharose. The antigenantibody-protein A-Sepharose-complex was collected by centrifugation and the supernatant was discarded or used for immunoprecipitations with other antibodies. The pellet was washed three times with $1 \mathrm{ml}$ of $300 \mathrm{~mm}-\mathrm{NaCl}, 1 \%$ Triton X-100, 0.1\% SDS and $50 \mathrm{mM}-\mathrm{Tris}-\mathrm{HCl}$ $\mathrm{pH} 8.0$ followed by three washes with $1 \mathrm{ml}$ of 125 mM-Tris- $\mathrm{HCl} \mathrm{pH}$ 6.8. Before the last of these washes the Sepharose beads were transferred to a new tube. The antigen was released by adding $50-100 \mu \mathrm{l}$ of $125 \mathrm{~mm}$-Tris- $\mathrm{HCl} \mathrm{pH} 6.8,2.5 \%$ 
G. HøYer-HANSEN et al.: Site of synthesis of a $15.2 \mathrm{kD}$ PSI polypeptide

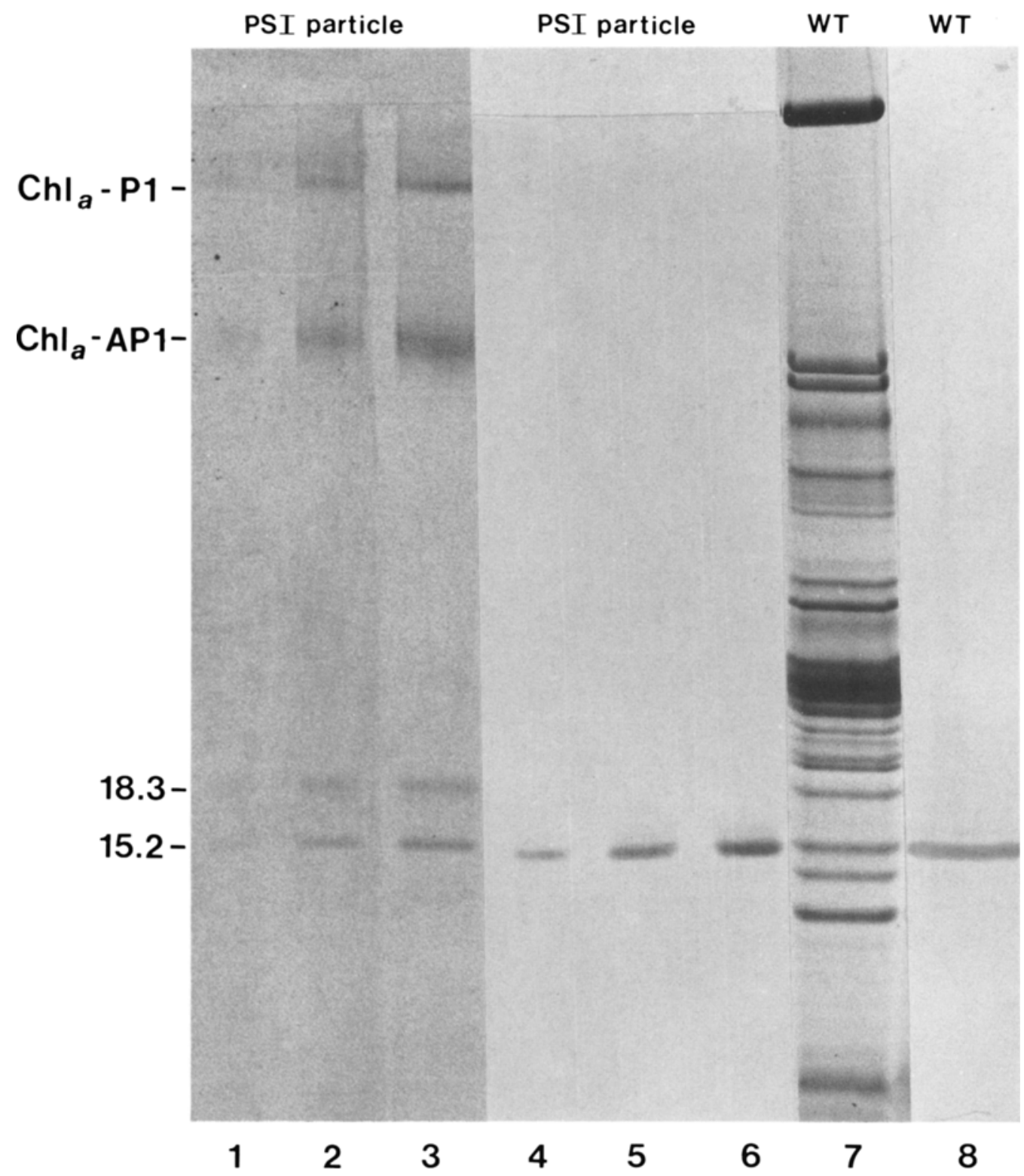

Figure 1. Monospecificity of CMp15.2:1.

PSI particles and chloroplast membrane polypeptides were separated on 11-15\% SDS-PAGE. Lanes 1, 2 and 3: 1,5 and $10 \mu \mathrm{g}$ of PSI particle proteins prior to transfer onto a nitrocellulose filter. The polypeptides were transferred to nitrocellulose filters. These were probed with CMp15.2:1. Lanes 4, 5, and 6: the nitrocellulose filter probed with $350 \mu \mathrm{g} \mathrm{CMp15.2:1.} \mathrm{Lane} \mathrm{7:} \mathrm{chloroplast} \mathrm{membrane} \mathrm{polypeptides} \mathrm{(20 \mu g} \mathrm{chlorophyll)} \mathrm{prior}$ to electro-blotting. Lane 8: nitrocellulose filter with thylakoid polypeptides probed with CMp15.2:1 (150 $\mu \mathrm{g})$.

SDS and $10 \%$ glycerol, and boiling for $2 \times 3 \mathrm{~min}$. The sample was centrifuged and the supernatant applied to SDS-gels.

After completion of the electrophoretic run the gels were transferred to $50 \%$ methanol and prepared for fluorography (8). The dried gels were exposed to either Kodak XRP-I or XAR-5 $\mathrm{X}$-Omat films at $-80^{\circ} \mathrm{C}$. 
The apparent molecular weights of immunoprecipitated polypeptides were estimated by coelectrophoresis with ${ }^{14} \mathrm{C}$-methylated molecular weight standards (Amersham); bovine serum albumin (69 kD), ovalbumin (45 kD), carbonic anhydrase $(30 \mathrm{kD})$, trypsin inhibitor $(21.5 \mathrm{kD})$, lysozyme $(14.3 \mathrm{kD})$, cytochrome $\mathrm{c}(12.5 \mathrm{kD})$ and aprotinin $(6.5 \mathrm{kD})$.

\section{RESULTS}

3.1. Characterization of three monoclonal antibodies to the $15.2 \mathrm{kD}$ polypeptide

To test the monospecificity of the antibody used, the following experiments were performed (Figure 1). Three different protein concentrations of PSI particles were separated on SDS-gels and blotted over to nitrocellulose filters. The filters were incubated with an excess of antibody $(\sim 350 \mu \mathrm{g})$. In all cases there is reaction with the $15.2 \mathrm{kD}$ polypeptide band only (Figure 1 , lanes $4,5,6)$. This is also the case when total thylakoid polypeptides (Figure 1, lane 8 ) or barley leaf protoplasts (21) are probed with the antibodies.

The intensity of antibody labelling of the $15.2 \mathrm{kD}$ band was the same, when incubated with $150 \mu \mathrm{g}$ of $\mathrm{CMp} 15.2: 1$, or $150 \mu \mathrm{g}$ of CMp15.2:1 plus $150 \mu \mathrm{g}$ of CMp15.2:2 (Figure 2). However, when $150 \mu \mathrm{g}$ of CMp15.2:1 was added with $150 \mu \mathrm{g}$ of CMp15.2:3, the intensity of labelling of the $15.2 \mathrm{kD}$ band was markedly increased (Figure 2, lane 3). This showed that CMp15.2:1 and CMp15.2:2 both recognized the same antigenic site and CMp15.2:3 reacted with a different antigenic site on the $15.2 \mathrm{kD}$ polypeptide. An immunodiffusion test classified CMp15.2:1 and CMp15.2:2 as IgG's, whereas CMp15.2:3 was an IgM.

\subsection{The intracellular location of transcripts for the $15.2 \mathrm{kD}$ polypeptide}

For immunoprecipitations we tried a wide concentration range of CMp15.2:1. Clear and specific precipitation bands were obtained with 25-30 $\mu$ l of hybridoma supernatant $(-0.63-$ $0.75 \mu \mathrm{g}$ of antibody). According to $\mathrm{K}$. STEINMÜllER (personal communications) mouse antibodies precipitate better at $\mathrm{pH} 8.0$ than at $\mathrm{pH}$ 7.4. We found this to be true also for our monoclonal antibodies.

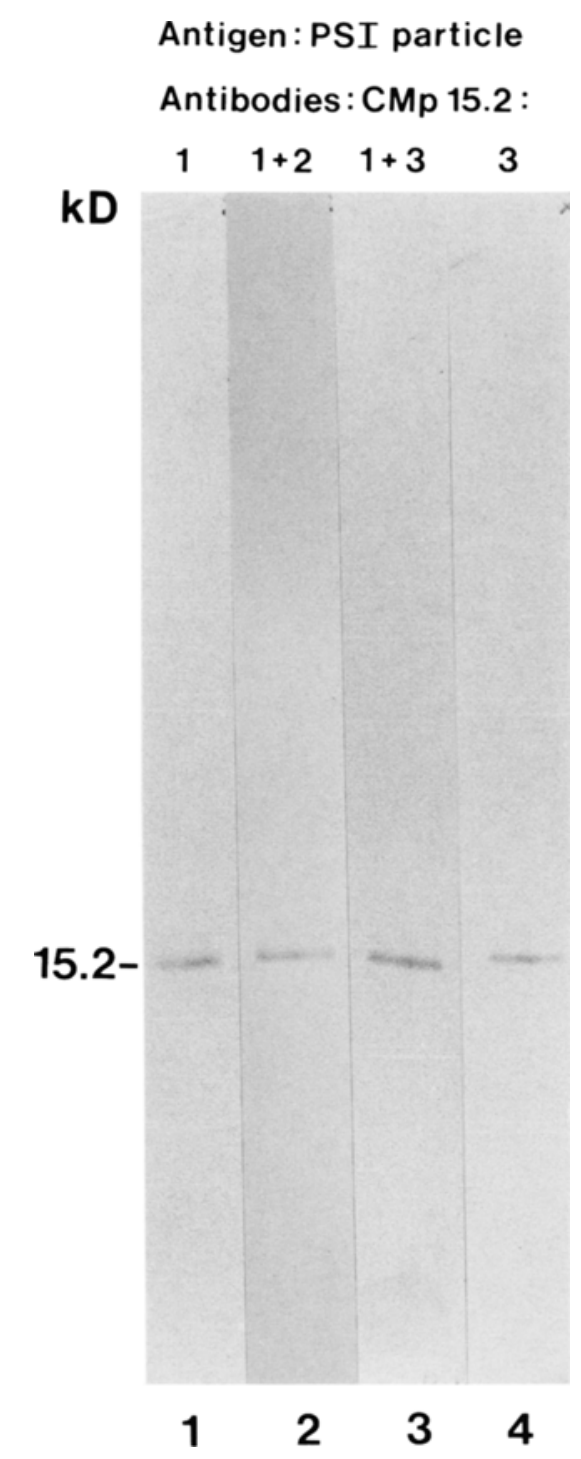

Figure 2. Reaction at different antigenic sites.

One $\mu \mathrm{g}$ of PSI particle was loaded in each slot and separated in 11-15\% SDS-PAGE. The separated polypeptides were transferred to nitrocellulose filter and probed with three different monoclonal antibodies to the $15.2 \mathrm{kD}$ polypeptide subunit of PSI. Nitrocellulose filter probed with, lane 1: $150 \mu \mathrm{g} \mathrm{CMp} \mathrm{15.2:1;} \mathrm{lane}$ 2: $150 \mu \mathrm{g} \mathrm{CMp15.2:1} \mathrm{and} 150 \mu \mathrm{g} \mathrm{CMp15.2:2;} \mathrm{lane}$ 3: $150 \mu \mathrm{g} \mathrm{CMp15.2:1} \mathrm{and} \mathrm{150 \mu g} \mathrm{CMp15.2:3} \mathrm{and} \mathrm{lane}$ 4: $150 \mu \mathrm{g} \mathrm{CMp15.2:3.}$

The polypeptide patterns of greening barley indicate that the $15.2 \mathrm{kD}$ polypeptide is synthesized during greening (19). Therefore, the intra- 


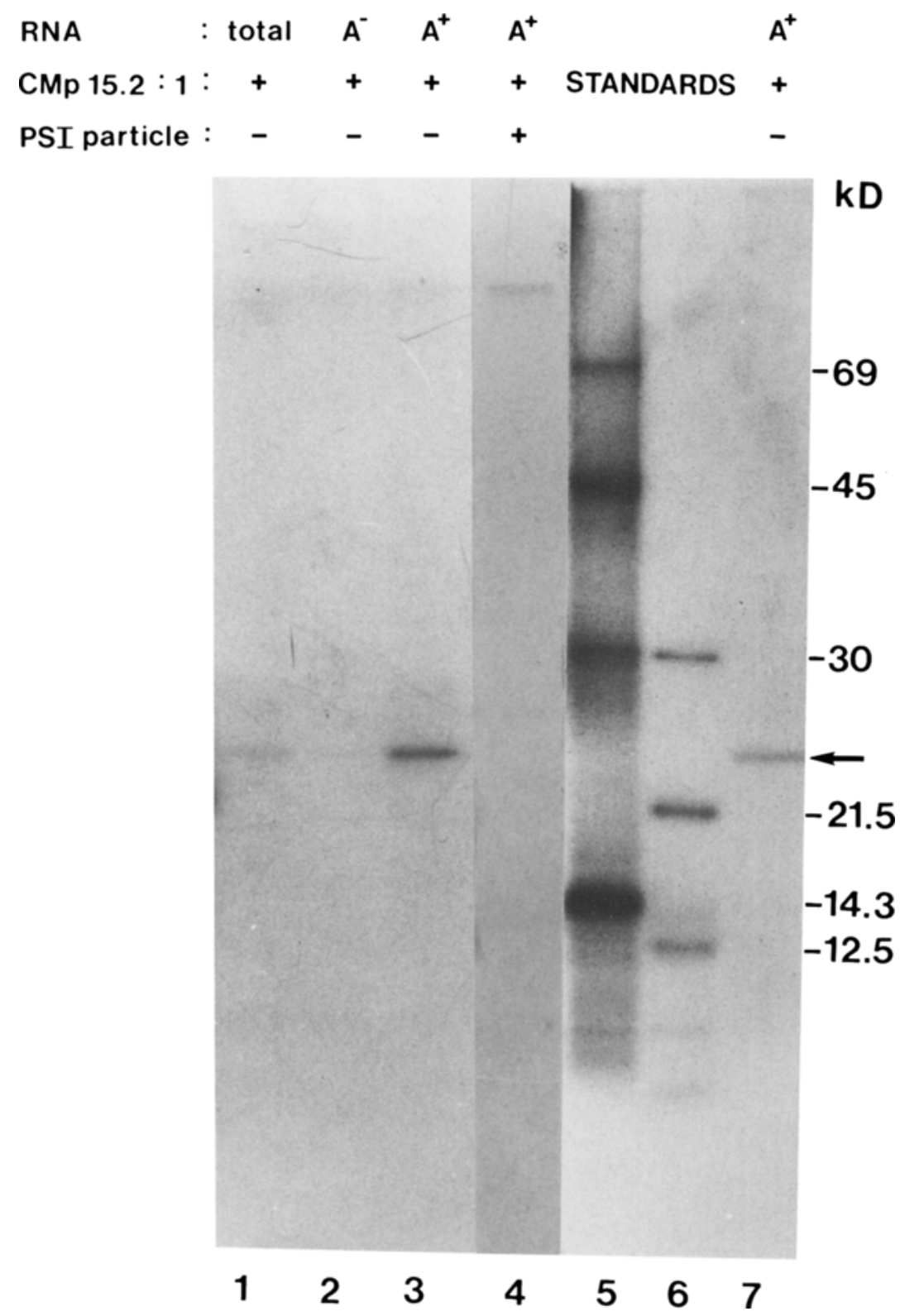

Figure 3. The intracellular location of transcripts for the $15.2 \mathrm{kD}$ PSI polypeptide.

Total RNA, poly $\mathrm{A}^{-}$and poly $\mathrm{A}^{+} \mathrm{RNA}$ were used as templates for in vitro translations. Immunoprecipitation of the translates was carried out using CMp15.2:1 $(0.63 \mu \mathrm{g})$. The autoradiogram shows the immunoprecipitated polypeptides after in vitro translation primed with total (lane 1 ), poly $\mathrm{A}^{-}$(lane 2 ), poly $\mathrm{A}^{+}$(lane 3 ) and poly $A^{+}$RNA after posttranslational addition of $40 \mu \mathrm{g}$ PSI particle preparation (lane 4). Co-electrophoresis with ${ }^{14} \mathrm{C}$-methylated standard proteins (lanes 5 and 6) for molecular weight determination (see 2.7) of the precursor polypeptide made from poly $\mathrm{A}^{+} \mathrm{RNA}$ (lane 7 ).

cellular location of transcripts for the $15.2 \mathrm{kD}$ PSI polypeptide subunit was studied by in vitro translation of poly $\mathrm{A}^{-}$, poly $\mathrm{A}^{+}$, plastid (pt) and total RNA isolated from greening barley. Immunoprecipitation carried out with $0.63 \mu \mathrm{g}$ CMp15.2:1 gave precipitation of a distinct poly- 
peptide only when total RNA and poly $\mathrm{A}^{+} \mathrm{RNA}$ served as a template (Figure 3, lanes 1 and 3), whereas poly $A$ and ptRNA yielded no precipitable translation products (Figure 3, lane 2, Figure 5, lane 6). However, when the translation products were probed with a monoclonal antibody to the $\alpha$-subunit of $\mathrm{CF}_{1}$, no precipitation occurred with poly $A^{+}$RNA but clearly from pt or poly ARNA stimulated translation mixtures (17). Based on the criterion that cytosolic mRNAs are polyadenylated in contrast to plastid mRNAs (44) the results indicate that the $15.2 \mathrm{kD}$ PSI polypeptide subunit is nuclear coded.

The apparent molecular weight of the immunoprecipitated polypeptide was $23 \mathrm{kD}$ as estimated by co-electrophoresis with radioactive standard proteins (Figure 3, lanes 5 and 6). With other marker proteins the size of the mature protein was previously determined by electrophoretic mobility to be $15.2 \mathrm{kD}$ (14). Using the ${ }^{14} \mathrm{C}$-labelled marker proteins we recalculated the molecular weight of the mature protein to be $18.8 \mathrm{kD}$. The precursor protein thus seems about $4.2 \mathrm{kD}$ larger than the mature protein. The relationship between the precipitated translation products and its mature counterpart was substantiated by competition experiments. If CMp15.2:1 $(0.63 \mu \mathrm{g})$ was incubated with $40 \mu \mathrm{g}$ PSI particle prior to its addition to the translate no precipitation of the $23 \mathrm{kD}$ polypeptide took place (Figure 3, lane 4).

\subsection{Immunoprecipitation of the pre-15.2 $\mathrm{kD}$ polypeptide using three different mono- clonal antibodies}

It is essential that the antibody binds to protein A for the recovery of an immunoprecipitate in the procedure used. Protein A binds only to the Fc part of an IgG molecule $(13,25)$, but by introducing a secondary antibody of the IgG class it should be possible to immunoprecipitate with an antibody of the IgM class.

CMp15.2:1, 2 and 3 all reacted with the mature $15.2 \mathrm{kD}$ polypeptide in immune-blot assays (Figure 2). In these the antigen-antibody binding was visualized with the aid of peroxidase coupled rabbit antimouse immunoglobulins. We thuschose rabbit immunoglobulins to mouse

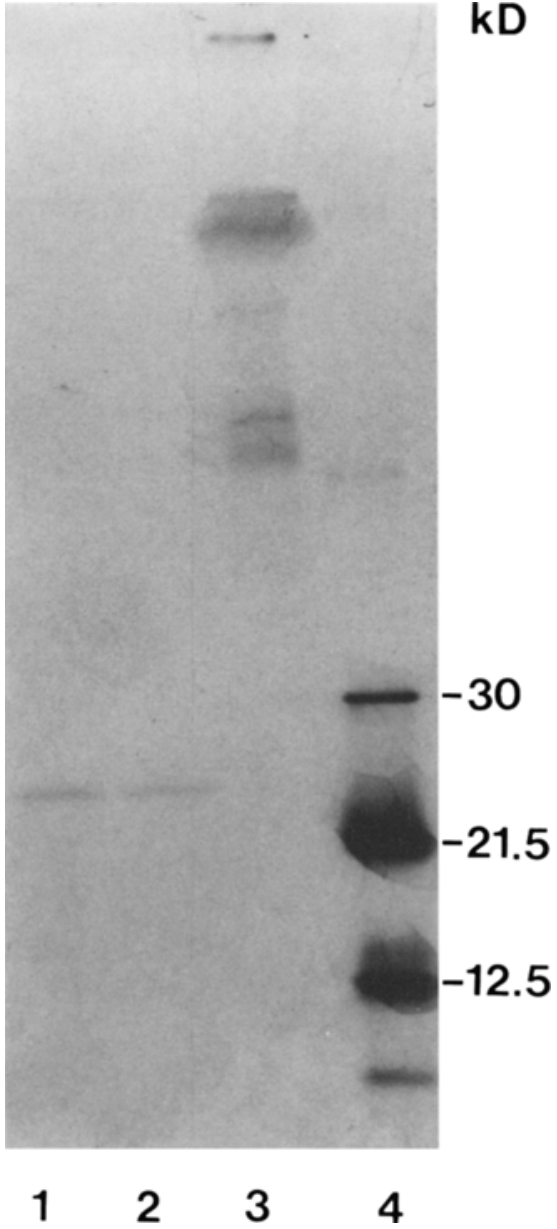

Figure 4. Immunoprecipitation of the precursor polypeptide with two monoclonal IgG's and one IgM.

In vitro translates primed with poly $\mathrm{A}^{+} \mathrm{RNA}$ were subjected to immunoprecipitation. Lane 1: $0.63 \mu \mathrm{g}$ CMp 15.2:1 and lane 2: 0.63 $\mu \mathrm{g} \mathrm{CMp15.2:2} \mathrm{were} \mathrm{added}$ to the translate. Lane 3 shows the precipitation bands obtained when the IgM CMp15.2:3 is used in combination with rabbit immunoglobulins to mouse immunoglobulins. Lane 4 shows ${ }^{14} \mathrm{C}$-methylated standard proteins.

immunoglobulins as the secondary antibody for immunoprecipitation with IgM antibodies.

An in vitro translation primed with poly $\mathrm{A}^{+}$ RNA was performed, and after termination the translate was divided into three aliquots, which were used for immunoprecipitation (Figure 4). When $0.63 \mu \mathrm{g}$ of CMp15.2:1 (lane 1) or CMp15.2:2 (lane 2) were added a clear precipita- 


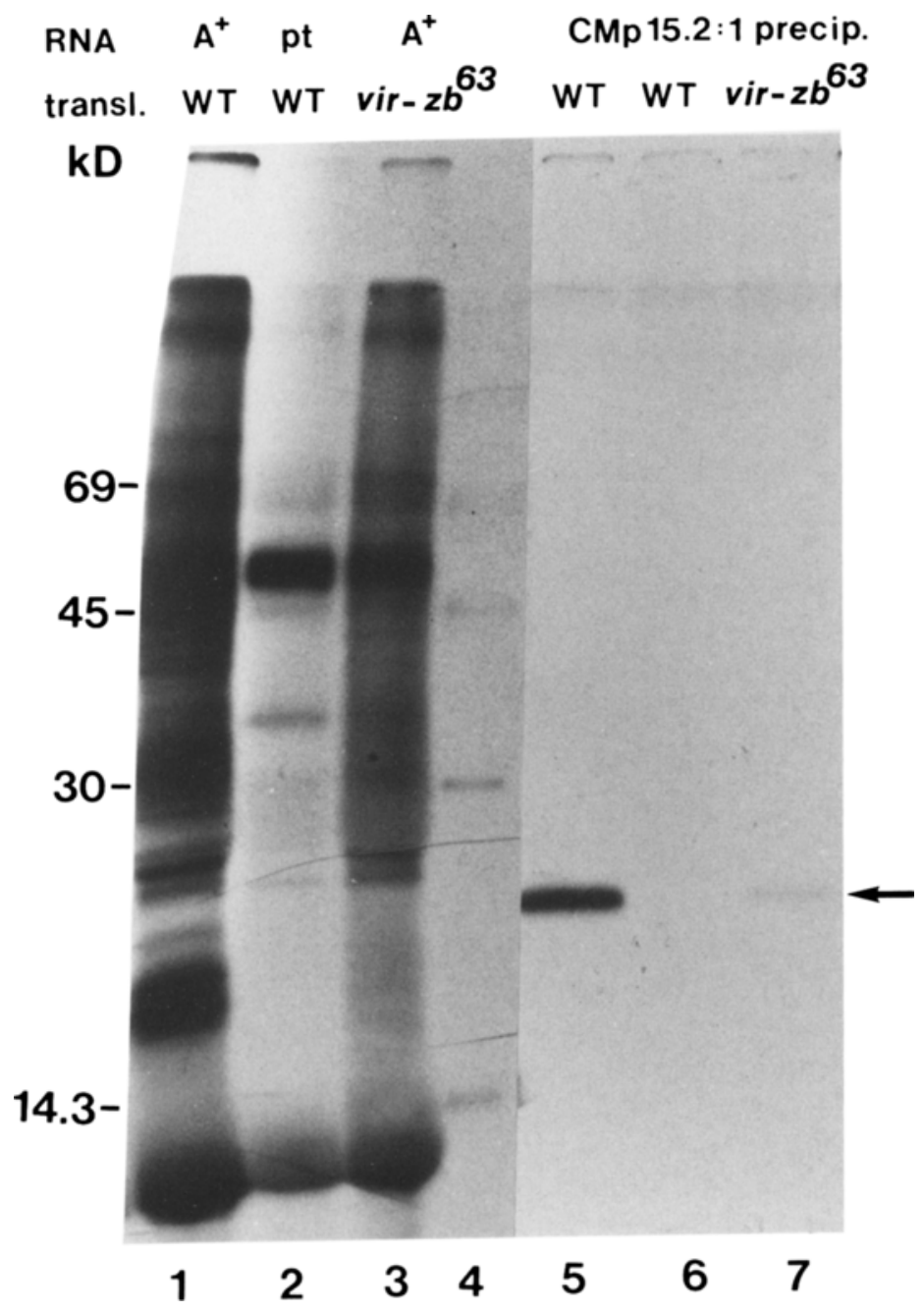

Figure 5. Presence of transcripts for the $15.2 \mathrm{kD}$ polypeptide in viridis- $z b^{63}$.

The autoradiogram shows the total products after in vitro translation primed with wild-type poly $\mathrm{A}^{+} \mathrm{RNA}$ (lane 1), wild-type ptRNA (lane 2 ) and viridis- $z b^{63}$ poly $\mathrm{A}^{+} \mathrm{RNA}$ (lane 3 ). Lane 4 shows ${ }^{14} \mathrm{C}$-methylated standard proteins. Immunoprecipitation using in each case $0.63 \mu \mathrm{g}$ of $\mathrm{CMp} 15.2: 1 \mathrm{of}$; lane 5 : in vitro translate primed with wild-type poly $A^{+} R N A$; lane 6 : in vitro translate primed with wild-type ptRNA; lane 7 : in vitro translate primed with poly $\mathrm{A}^{+} \mathrm{RNA}$ from viridis- $z b^{63}$.

tion band at $23 \mathrm{kD}$ was seen. Immunoprecipitation with the IgM, CMp15.2:3, using the secondary rabbit antibody gave rise to at least three high molecular weight bands but nothing at $23 \mathrm{kD}$ (Figure 4, lane 3). Even though a wide concentration range of secondary antibody was tried, it was not possible to obtain a $23 \mathrm{kD}$ precipitation band with $\mathrm{CMp15.2:3.} \mathrm{Immunoprecipitations}$ with IgM antibodies to other thylakoid polypep- tides have resulted in either diffuse, weak bands or none at all (17).

\subsection{Presence of transcripts of the $15.2 \mathrm{kD}$ polypeptide in the PSI mutant viridis- $z b^{63}$}

The nuclear gene mutant viridis- $z b^{63}$ has been shown to completely lack PSI activity (14) and the associated EPR signals (32). In the polypep- 
tide pattern of the mutant $(14,21,31)$ the 18.3 and $15.2 \mathrm{kD}$ PSI polypeptides are not detectable. Comparison of the total products from in vitro translation of poly $\mathrm{A}^{+} \mathrm{RNA}$ from viridis- $z b^{63}$ and wild-type (Figure 5, lanes 1 and 3) showed a decrease of translated polypeptides in the 25-15 $\mathrm{kD}$ range in the mutant. However, the transcripts for the $23 \mathrm{kD}$ precursor polypeptide was detected among the mutant poly $\mathrm{A}^{+} \mathrm{RNA}$ (Figure 5 , lane 7). The amount of radioactivity incorporated into the mutant polypeptide was lower than in the wild-type, but this could be because the mutant RNA was isolated from plants of a later developmental stage (see Materials and Methods, 2.1).

\section{DISCUSSION}

Monoclonal antibodies have been prepared to the three Coomassie stainable polypeptide subunits of the barley PSI particle $(15,17,18$, 21 , with the aim of determining their sites of synthesis. We obtained both IgG and IgM secreting hybridomas to the chlorophyll $a$-protein 1 and the $15.2 \mathrm{kD}$ protein. The epitope specificity of the obtained monoclonal antibodies varied. Antibodies recognizing at least four different epitopes on the chlorophyll $a$-protein 1 have been identified (HøYER-HANSEN, in preparation), whereas so far only antibodies to two different epitopes on the $15.2 \mathrm{kD}$ polypeptide have been found (Figure 2). These will be useful for peptide mapping. Only one hybridoma secreting IgM antibodies to the $18.3 \mathrm{kD}$ protein was found. It was initially thought that IgMs were suitable for immunoprecipitations by introducinga secondary antibody of the IgG class. Rabbit antimouse immunoglobulins reacted well with the monoclonal IgM's in immune-blot assays $(15,16,17,21)$, but immunoprecipitation with the monoclonal IgM's was not successful (Figure 4). It was thus not possible for us to determine the site of synthesis of the $18.3 \mathrm{kD}$ PSI polypeptide (17). One explanation for the failure could be that the IgM molecules prevent the binding of protein A-Sepharose to the rabbit IgG molecules by steric hindrance.

The biosynthesis of the thylakoid membrane involves protein synthesis in both the chloro- plast and the cytosol. Inhibitor studies $(29,33)$ and work with photosynthetic mutants $(6,11$, $12,14,20,31$ ) have shown that there is a cooperation between nuclear and plastid genes. The main component of the PSI protein complex, the chlorophyll $a$-protein 1 , is synthesized on chloroplast ribosomes $(20,29,33)$ and is chloroplast coded (42). The sites of synthesis of some of the other components have been determined with the aid of inhibitors $(29,33)$ and by mRNA-dependent cell-free protein synthesis (42). The results obtained are difficult to compare due to the different methods, species and nomenclature used. However, using the apparent molecular weight as a guide the spinach subunit 2 corresponds to the barley 18.3 $\mathrm{kD}$ PSI polypeptide. The molecular weight of the barley polypeptide as determined by amino acid composition is $21.3 \mathrm{kD} \mathrm{(21)}$ and that of the spinach subunit 2 is $22 \mathrm{kD}(42)$. The spinach subunit 2 was found to be nuclear coded with a transit sequence of $4 \mathrm{kD}(42)$. We have shown that the barley $15.2 \mathrm{kD}$ PSI polypeptide is synthesized as a precursor about $4.2 \mathrm{kD}$ larger than the mature protein. The transcripts are found among the poly $A^{+}$RNA showing that the protein is nuclear coded. The apparent molecular weight of the barley $15.2 \mathrm{kD}$ protein when recalculated with the radioactive protein standards was found to be $18.8 \mathrm{kD}$ in agreement with that determined from amino acid composition (21). On the basis of this it is hard to decide, if it corresponds to the spinach subunit 3 or 4 which by gel electrophoresis have apparent molecular weights of 18.5 and $18 \mathrm{kD}$, respectively (42). In pea, cDNA clones have been isolated for an early light-induced nuclear coded chloroplast membrane protein. The precursor protein has a molecular weight of $24 \mathrm{kD}$ and the mature protein after import into the chloroplast has a molecular weight of $17 \mathrm{kD}$ (37). The function of this pea protein is unknown.

The nuclear gene mutant viridis- $z b^{63}$ contains transcripts for the $23 \mathrm{kD}$ precursor polypeptide and small amounts of both the 18.3 and 15.2 $\mathrm{kD}$ proteins are incorporated into its membranes, as shown by immune-blot assays (21). It will be interesting to determine, if the transcripts for the chlorophyll $a$-protein 1 are among the chloroplast RNA of viridis- $z b^{63}$. 


\section{ACKNOWLEDGEMENTS}

We wish to thank Professor DITER VON WETTSTEIN and Dr. DAvidSIMPSON for stimulating discussions and critical review of the manuscript. We are grateful to TOM BEKTVED for excellent technical assistance. We also thank Nina Rasmussen, ANN-SOFI SteINHOLtZ, HANNE THEM NiElSEN and LiSE TRILlot for helping us preparing the figures and the manuscript.

\section{REFERENCES}

1. ANDERSON, D. J. \& G. BLOBEL: Immunoprecipitation of proteins from cell-free translations. In: Meth. Enzymol. Vol 96, Biomembranes Part J. S. Fleischer \& B. Fleischer eds., pp. 111-121 (1983)

2. ARNON, D. I.: Copper enzymes in isolated chloroplasts. Polyphenoloxidase in Beta vulgaris. Plant Physiol. 24, 1-14 (1949)

3. Bassi. R., O. MACHOld \& D. Simpson: Chlorophyll-proteins of two photosystem I preparations from maize. Carlsberg Res. Commun. 50, 127-143 (1985)

4. Bengis, C. \& N. Nelson: Purification and properties of the photosystem I reaction center from chloroplasts. J. Biol. Chem. 250, 2783-2788 (1975)

5. Bengis, C. \& N. Nelson: Subunit structure of chloroplast photosystem I reaction center. J. Biol. Chem. 252, 4564-4569 (1977)

6. Bennoun, P., J. Girard \& N. -H. Chua: A uniparental mutant of Chlamydomonas reinhardii deficient in the chlorophyll-protein complex CPI. Mol. Gen. Genet. 153, 343-348 (1977)

7. BRANDT, A. \& J. INGVERSEN: Isolation and translation of hordein messenger RNA from wild type and mutant endosperm in barley. Carlsberg Res. Commun. 43, 451-469 (1978)

8. Chamberlain, J. P.: Fluorographic detection of radioactivity in polyacrylamide gels with the water-soluble fluor, sodium salicylate. Anal. Biochem. 98, 132-135 (1979)

9. Chrigwin, J. M., A. E. Przybyla, R. J. MacDoNALD \& W. J. RUTTER: Isolation of biologically active ribonucleic acid from sources enriched in ribonuclease. Biochemistry 18, 5294-5299 (1979)

10. Chua. N. -H. \& P. Bennoun: Thylakoid membrane polypeptides of Chlamydomonas reinhardtii: Wild-type and mutant strains deficient in photosystem II reaction center. Proc. Nat. Acad. Sci., USA 72, 2175-2179 (1975)

11. Chua, N. -H., K. Matlin \& P. Bennoun: A chlorophyll-protein complex lacking in photosystem
I mutants of Chlamydomonas reinhardtii. J. Cell. Biol. 67, 361-377 (1975)

12. Girard, J., N. -H. Chua, P. Bennoun, G. SCHMidT \& M. Delosme: Studies on mutants deficient in the photosystem $I$ reaction centers in Chlamydomonas reinhardtii. Current Genet. 2, 215-221 (1980)

13. Goding, J. W.: Use of Staphylococcal protein A as an immunological reagent. J. Immunol. Meth. 20, 241-253 (1978)

14. Hiller, R.G., B. L. Møller \& G. Høyer-Hansen: Characterization of six putative photosystem I mutants in barley. Carlsberg Res. Commun. 45, 315-328 (1980)

15. HønberG, L. S.: Monoclonal antibodies to $23 \mathrm{kD}$ and $18.3 \mathrm{kD}$ barley thylakoid polypeptides. In: Advances in Photosynthesis Research, C. Sybesma ed., M. Nijhoff/Dr. W. Junk Publishers, The Hague, The Netherlands, Vol IV, pp. 525-528 (1984)

16. HønBerg, L. S.: Probing barley mutants with a monoclonal antibody to a polypeptide involved in photosynthetic oxygen evolution. Carlsberg Res. Commun. 49, 703-719 (1984)

17. Hønberg, L. S.: Monoclonal antibodies to components of photosystem I and II. Cand. scient. Thesis, Copenhagen University (1985)

18. Høyer-Hansen, G.: Monoclonal antibodies to chlorophyll $a$-protein 1 in barley. In: Advances in Photosynthesis Research, C. Sybesma ed., M. Nijhoff/Dr. W. Junk Publishers, The Hague, The Netherlands, Vol III, pp. 171-174 (1984)

19. Høyer-Hansen, G. \& D. J. Simpson: Changes in the polypeptide composition of internal membranes of barley plastids during greening. Carlsberg Res. Commun. 42, 379-389 (1977)

20. Høyer-Hansen, G. \& G. Casadoro: Unstable chloroplast ribosomes in the cold-sensitive barley mutant tigrina- $o^{34}$. Carlsberg Res. Commun. 47, 103-118 (1982)

21. Høyer-Hansen, G., L. S. Hønberg \& D. J. SimpSON: Monoclonal antibodies used for the characterization of the two putative iron-sulphur centre proteins associated with photosystem I. Carlsberg Res. Commun. 50, 23-35 (1985)

22. Kannangara, G. C., S. P. Gough, B. Hansen, J. N. RASMUSSEN \& D. J. SimPSON: A homogenizer with replaceable razor blades for bulk isolation of active barley plastids. Carlsberg Res. Commun. 42, 431-439 (1977)

23. Kohler, G. \& C. Milstein: Continuous cultures of fused cells secreting antibodies of predefined specificity. Nature 256, $495-497$ (1975)

24. LAGOUtTE, B., P. SETIF \& J. DuRANTON: Tentative identification of the apoproteins of the iron-sulfur 
centers of photosystem I. FEBS Lett. 174, 24-29 (1984)

25. LANGONE, J. J: : $\left({ }^{125} \mathrm{I}\right)$ protein A: A tracer for general use in immunoassay. J. Immunol. Meth. 24, 269-285 (1978)

26. Lowry, O. H., N. J. Rosebrough, A. L. FARR \& R. J. Randall: Protein measurement with the Folin phenol reagents. J. Biol. Chem. 193, 265-275 (1951)

27. Mullet, J. E., J. J. Burke \& C. J. ARntzen: Chlorophyll proteins of photosystem I. Plant Physiol. $65,814-822$ (1980)

28. Mullet,J.E., K. Leto\& C.J.ARNTZEN: Structural organization and development of the light-harvesting pigment proteins for photosystem I and II. In: G. Akoyunoglou ed., Photosynthesis V. Chloroplast Development, Balaban Int. Services, Philadelphia, Pa. 1981, pp. 557-568

29. Mullet, J. E., A. R. Grossman \& N. -H. Chua: Synthesis and assembly of the polypeptide subunits of photosystem I. Cold Spring Harbor Symp. Quant. Biol. 46, 979-984 (1982)

30. Møller, B. L., R. M. SMillie \& G. Høyer-HaNSEN: A photosystem I mutant in barley (Hordeum vulgare L. ). Carlsberg Res. Commun. 45, 87-99 (1980)

31. Møller, B.L.,G.Høyer-HanSEN\& R.G.HilleR: Functional identification of barley thylakoid polypeptides resolved by SDS-polyacrylamide gel electrophoresis. In: G. Akoyunoglou ed. Photosynthesis III. Structure and Molecular Organisation of the Photosynthetic Apparatus, Balaban Int. Services, Philadelphia, Pa. 1981, pp. 245-256

32. MølLER, B. L., J. H. A. Nugent \& M.C. W. Evans: Electron paramagnetic resonance spectrometry of photosystem I mutants in barley. Carlsberg Res. Commun. 46, 373-382 (1981)

33. Nechushtai, R, N. Nelson, A. K. Mattoo \& M. EDELMAN: Site of synthesis of subunits to photosystem I reaction center and the proton-ATPase in Spirodela. FEBS Lett. 125, 115-119 (1981)

34. OKITA, T. W. \& F. C. GREENE: Wheat storage proteins. Isolation and characterization of the gliadin messenger RNAs. Plant Physiol. 69, 834-839
(1982)

35. POULSEN, C.: The barley chloroplast genome: physical structure and transcriptional activity in vivo. Carlsberg Res. Commun. 48, 57-80 (1983)

36. Przybyla, A. E., R. J. MacDonald, J. D. HardING. R. L. PICTET \& W. J. RutTER: Accumulation of the predominant pancreatic mRNAs during embryonic development. J. Biol. Chem. 254, 2154-2159 (1979)

37. SCharnhorst, C., H. Heinze, G. Meyer, W. Kolanus, K. Bartsch, S. Heinrichs, T. GudsCHUN, M. Møller \& F. HerzFeld: Molecular cloning of a pea mRNA encoding an early light induced, nuclear coded chloroplast protein. Plant Mol. Biol. 4, 241-245 (1985)

38. Schreier, M., G. Kohler, H. Hengartner, C. Berek, T. Trucco, L. Forni, T. Staehelin, J. STOCKER \& B. TAKACS: Hybridoma techniques, EMBO, SKMB course 1980, Basel p. 26.

39. Takahashi, Y. \& S. Katoh: Functional subunit structure of photosystem 1 reaction center in Synechococcus sp. Arch. Biochem. Biophys. 219, 219-227 (1982)

40. Towbin, H.. T. STAehelin \& J. GoRdon: Electrophoretic transfer of proteins from polyacrylamide gels to nitrocellulose sheets: Procedure and some applications. Proc. Nat. Acad. Aci., USA 76, 43504354 (1979)

41. Westhoff, P.. N. Nelson, H. BÜNEMANN \& R. G. HerRmanN: Localization of genes for coupling factor subunits on the spinach plastid chromosome. Current Genet. 4, 109-120 (1981)

42. Westhoff, P., J. Alt, N. Nelson, W. BottomLEY, H. Búnemann \& R. G. Herrmann: Genes and transcripts for the $\mathrm{P}_{700}$ chlorophyll $a$ apoprotein and subunit 2 of the photosystem I reaction center complex from spinach thylakoid membranes. Plant Mol. Biol. 2, 95-107 (1983)

43. WeTtSTEIN, D. vON \& K. KRISTIANSEN: Stock list for nuclear gene mutants affecting the chloroplast. Barley Genet. Newslett. 3, 113-117 (1973)

44. WHEELER, A. M. \& M. R. HARTLEY: Major mRNA species from spinach chloroplasts do not contain poly(A). Nature 257, 66-67 (1975) 